\title{
Effectivity of arbuscular mycorrhizal fungi collected from reclaimed mine soil and tallgrass prairie
}

\author{
Mark Thorne $^{1^{*}}$, Landon Rhodes ${ }^{2}$, John Cardina $^{3}$ \\ ${ }^{1}$ Environmental Science Graduate Program, The Ohio State University, Columbus, USA; \\ *Corresponding Author: thorne.36@osu.edu \\ ${ }^{2}$ Department of Plant Pathology, The Ohio State University, Columbus, USA \\ ${ }^{3}$ Department of Horticulture and Crop Science, Ohio Agricultural and Research Development Center, \\ The Ohio State University, Columbus, USA
}

Received 10 April 2013; revised 17 May 2013; accepted 23 June 2013

Copyright (C) 2013 Mark Thorne et al. This is an open access article distributed under the Creative Commons Attribution License, which permits unrestricted use, distribution, and reproduction in any medium, provided the original work is properly cited.

\section{ABSTRACT}

We examined suitability of arbuscular mycorrhizal fungi (AMF) associated with cool-season nonnative forages on reclaimed surface-mined land in southeast Ohio for establishment of native warm-season grasses. The goal of establishing these grasses is to diversify a post-reclamation landscape that is incapable of supporting native forest species. A 16-week glasshouse study compared AMF from a 30-year reclaimed mine soil (WL) with AMF from native Ohio tallgrass prairie soil (CL). Four native grasses were examined from seedling through 16 weeks of growth. Comparisons were made between $C L$ and WL AMF on colonized (+AMF) and non-colonized plants (-AMF) at three levels of soil phosphorus (P). Leaves were counted at 4 week intervals. Shoot and root biomass and percent AMF root colonization were measured at termination. We found no difference between WL and CL AMF. Added soil $P$ did not reduce AMF colonization, but did reduce AMF efficacy. Big bluestem (Andropogon gerardii Vitman), Indiangrass (Sorghastrum nutans (L.) Nash), and tall dropseed (Sporobolus asper (Michx.) Kunth) benefited from AMF only at low soil $P$ while slender wheatgrass (Elymus trachycaulus (Link) Gould ex Shinners) exhibited no benefit. Establishment of tallgrass prairie dominants big blue-stem and Indiangrass would be supported by the mine soil AMF. It appears that the non-native forage species have supported AMF equally functional as AMF from a regionally native tallgrass prairie. Tall dropseed and slender wheatgrass were found to be less dependent on AMF than big bluestem or Indian- grass and thus would be useful in areas with little or no AMF inoculum.

Keywords: Arbuscular Mycorrhizal Fungi; Mycorrhizae; Ecosystem Restoration; Surface Mining; Calcareous Mine Soil; Prairie Grasses

\section{INTRODUCTION}

Surface coal mining negatively impacts landscapes by altering soil structure and chemistry, and negatively affects beneficial soil organisms such as AMF. Topsoil removal and stockpiling prior to mining destroys active AMF symbiosis and diminishes soil inoculum potential and AMF species composition [1,2]. This impact may inhibit establishment of AMF-dependent species during reclamation and restoration.

Arbuscular mycorrhizal fungi benefit establishment of many plant species on reclaimed mine soils [2-5]. The symbiotic function of these organisms is critical for supplying plants with minerals, primarily phosphorus, in exchange for organic energy compounds [6-10]. This relationship is critical to plant survival especially when soil phosphorus is low [11]. In addition, AMF may affect plant community composition and successional trajectories by differentially benefiting some plants over others [12-20].

While AMF symbiosis is common and occurs in nearly every terrestrial environment [9], differences in the effectiveness of AMF occur over the landscape and in response to management history $[20,21]$. Strains of AMF from infertile soil are more effective at phosphorus transfer to plants than AMF from fertile soil [22]. Greater effectivity has been found in AMF from zinc-contaminated soil as well other stressful habitats [23,24]. These studies suggest that in harsh, low-nutrient habitats, there is selection for superior AMF strains. Furthermore, a certain 
degree of host-plant-specificity occurs between AMF and host plants [25-28]. Therefore, more effective strains of AMF may benefit re-establishment of native vegetation in disturbed habitats, as long as host-specificity is not a barrier.

In southeast Ohio, surface coal mine reclamation practices since 1972 have converted nearly 80,000 hectares of native deciduous forestland to non-native forage grassland [29]. In 1972, reclamation laws required that overburden be contoured to approximate the original landscape form, and stockpiled topsoil be spread over the newly-constructed landscape causing severe compaction on the constructed landscape. Furthermore, revegetation did not require native species if preapproved plans stated otherwise [30]. In place of native forest species, nonnative forage species such as tall fescue (Festuca arundinaceae Schreb.), Kentucky bluegrass (Poa pratensis L.), and birdsfoot trefoil (Lotus corniculatus L.) were planted because they established easily and tolerated soil compaction caused by the reclamation procedures. These cool-season forages produce a thick ground cover important for controlling erosion and have potentially maintained AMF across the landscape.

Replacing the non-native forage complex with regionally native prairie species is one alternative for increasing biodiversity and ecosystem function on reclaimed mine sites that are incapable of supporting native forest species. Tallgrass prairies are native to parts of Ohio and may represent a diverse set of species that could enhance the functional quality of the mined land [31-33]. However, it is unclear if AMF associated with the cool-season forage species currently growing on the reclaimed mined land would be effective in supporting tallgrass prairie vegetation. Warm-season tallgrass species are more dependent on AMF than cool-season grasses [11,34-36] and problems with host specificity or effectivity could delay or limit their establishment [37].

This research compares the infective and effective potential of AMF collected from a remnant central Ohio tallgrass prairie with AMF from reclaimed mine soil on growth of four native tallgrass prairie grasses. The grass species evaluated were big bluestem, Indiangrass, tall dropseed, and slender wheatgrass. Slender wheatgrass is a cool-season grass while big bluestem, Indiangrass and tall dropseed are warm-season species; all four occur throughout the central grassland region of North America, including tallgrass prairies [38]. The reclaimed mine soil examined in this study has supported a low-diversity non-native forage complex for 30 years. The tallgrass prairie remnant contains 177 plant species including signature tallgrass prairie species big bluestem, Indiangrass, tall dropseed, little bluestem (Schizachyrium scoparium (Michx.) Nash), and switchgrass (Panicum virgatum L.) [33].
The objectives of this research were 1) to determine if AMF associated with mine soil vegetation are as effective as native tallgrass prairie AMF in supporting native grass growth on reclaimed mine soil, and 2) to determine how these prairie grasses respond to each source of AMF when grown in soils with a range of soil phosphorus levels. The goal of this study was to identify growth responses of prairie grasses to AMF and phosphorus that would aid in developing strategies to increase biodiversity and ecosystem function on compacted reclaimed mine soil $[39,40]$.

\section{MATERIALS AND METHODS}

\subsection{AMF Sources and Pot Culture}

Soil containing CL AMF was collected from the Claridon tallgrass prairie remnant near Marion, Ohio. Mine soil containing WL AMF was collected from a reclaimed surface mined area near Cumberland, Ohio. The CL site is a 2.2 ha linear remnant owned by the CSX Railroad and is overseen by the Marion County Historical Society [33]. The WL site is located on land that had been surface mined in the early $1980 \mathrm{~s}$, and was once part of the Muskingum Mine, then owned and mined by Central Ohio Coal Company. In 1986, the land was donated to The International Center for the Preservation of Wild Animals, Inc. (the Wilds). The area is part of the Allegheny Plateau of southeast Ohio, which extends westward from the Allegheny Mountains and is a subdivision of the Appalachian Mountain Range.

Approximately 35 liters of soil were collected from each site during September, 2005. Soil from the surface $20 \mathrm{~cm}$ was collected from 15 to 20 randomly selected locations at each site. At the CL location, samples were collected alongside established prairie grasses big bluestem and Indiangrass, so that grass roots containing AMF would be included. At the WL location, soil was collected from an area supporting Kentucky bluegrass, tall fescue, and birdsfoot trefoil. These species were dominant throughout the reclaimed mined area. Pot cultures of each AMF source were prepared by mixing soil from each location, 1:1 by volume, with silica sand in a portable cement mixer, which was cleaned between mixes. The soil/sand mix was poured into 3.8-L plastic nursery containers and sown with white clover (Trifolium repens L.) as a host plant [41]. By using a legume inoculated with nitrogen fixing bacteria, instead of another grass, the pot cultures could be grown without having to add supplemental N. But, more importantly, this would reduce the chance of propagating pathogens specific to graminoids along with the AMF. The containers were placed on benches in a $20^{\circ} \mathrm{C}$ to $27^{\circ} \mathrm{C}$ glasshouse with artificial lighting $12 \mathrm{hr} \cdot \mathrm{day}^{-1}$. The pot cultures were watered daily without fertilizer for 10 months. Inoculum was prepared 
by chopping up soil and roots from each pot, discarding course roots and tops, then mixing all soil and fine roots together for each AMF source.

Sterile growing medium soil was prepared by mixing topsoil collected from the surface $20 \mathrm{~cm}$ at the WL site with silica sand, $1: 1$ by volume, in a portable cement mixer. The soil/sand mix was then steamed for $5 \mathrm{hr}$ at $100^{\circ} \mathrm{C}$. The sterile soil was stored in plastic bins for 21 days at $20^{\circ} \mathrm{C}$ prior to use in the experiment. Soil from each pot culture, the sterilized growing medium soil, and original $\mathrm{WL}$ topsoil were analyzed for $\mathrm{pH}, \mathrm{P}, \mathrm{K}, \mathrm{Ca}$, and Mg content by the Service Testing and Research Laboratory (STAR lab), The Ohio State University/Ohio Agricultural Research and Development Center, Wooster, $\mathrm{OH}$ (Table 1). Identification of AMF species was not attempted in this study; however, several Glomus species were noted in early examination of the source soils (personal observation). It is likely that WL AMF species were part of deciduous forest ecosystem present before mining; although much of the forested biome was deforested from agriculture in the late 1800 s. The CL AMF was associated with a historical tallgrass prairie in Northwest Ohio.

\subsection{Experiment Establishment and Design}

Experimental units consisted of individual grass seedlings growing in $660-\mathrm{cm}^{3}$ pots (D40 Deepot ${ }^{\mathbb{Q}}$, Stuewe and Sons, Inc., Corvallis, OR) containing $500 \mathrm{~cm}^{3}$ sterile growing medium soil plus one of four AMF inoculum treatments, and one of three $\mathrm{P}$ levels. Inoculum treatments included $100 \mathrm{~cm}^{3}$ of CL or WL pot-culture soil, or $100 \mathrm{~cm}^{3}$ of sterilized CL (CLS) or sterilized WL (WLS) pot culture soil. Sterilized inoculum soil was added to the AMF pots to control for possible fertilizer effects from the pot culture soil. The sterilized soil was prepared by autoclaving $8 \mathrm{~L}$ of each pot culture soil for $70 \mathrm{~min}$ at $130^{\circ} \mathrm{C}$, and then resting the soil in plastic bags at $4^{\circ} \mathrm{C}$ for $96 \mathrm{~h}$.

Three levels of P (P1, P2, P3) were established by mixing $0.0,0.1$, and $0.3 \mathrm{~g}$ triple super phosphate $(0-45$ 0) (Bonide Products Inc., Oriskany, NY) per $500 \mathrm{~cm}^{3}$ sterile soil plus the $100 \mathrm{~cm}^{3}$ inoculum soil to reach target $\mathrm{P}$ levels of 5,13 , and $27 \mathrm{mg} \cdot \mathrm{kg}^{-1}$, respectively. Calculations were based on the recommendation that $10 \mathrm{mg} \cdot \mathrm{kg}^{-1}$ $\mathrm{P}$ is required to increase available soil $\mathrm{P} 1 \mathrm{mg} \cdot \mathrm{kg}^{-1}$ (Dr. Donald Eckert, The Ohio State University, personal communication). Each pot was standardized for bacteria by adding $100 \mathrm{ml}$ of sievate corresponding to each particular AMF inoculum. The sievate for each inoculum was prepared by mixing $1000 \mathrm{~cm}^{3}$ pot culture soil and $16 \mathrm{~L}$ water, allowing the slurry to briefly settle, and pouring the liquid and suspended matter through a $53-\mu \mathrm{m}$ sieve.

The experiment was designed as a randomized complete block with a factorial arrangement of four levels of grass species, four levels of AMF source (CL, CLS, WL, and WLS), and three levels of P (P1, P2, and P3). Each treatment was replicated six times. The four grass species (SPP) were "Bison" big bluestem (Andropogon gerardii Vitman), "Tomahawk" Indiangrass (Sorghastrum nutans (L.) Nash), "Revenue" slender wheatgrass (Elymus trachycaulus (Link) Gould ex Shinners), and tall dropseed (Sporobolus asper (Michx.) Kunth). Big bluestem, Indiangrass, and slender wheatgrass were purchased from Western Native Seeds, Coaldale, CO USA, and tall dropseed was purchased from Oak Prairie Farm, Pardeeville, WI USA. Seeds of each species were sown $10-20$ per pot, and thinned to leave a single seedling in each pot.

Pots were placed in trays and arranged so that +AMF treatments were adjacent to $-\mathrm{AMF}$ control pots to allow for paired-pot comparisons of AMF sources. Trays were placed on a glasshouse bench in a randomized-block design such that blocks controlled for distance from the cooling/heating source on one end and exhaust fan at the other. Artificial lighting was set to maintain a minimum of $300 \mathrm{~W} \cdot \mathrm{m}^{-2} 16 \mathrm{~h} \cdot \mathrm{day}^{-1}$, and temperature ranged between $19^{\circ} \mathrm{C}-27^{\circ} \mathrm{C}$.

\subsection{Grass Leaf and Biomass Measurements}

At $4,8,12$, and 16 weeks following germination, living and dead leaves were counted on each plant. To reduce confusion in successive censuses, dead leaves were removed and stored for later biomass measurement. At the end of the 16-week experiment, plants were destructively harvested to assess aboveground and belowground biomass. Culms and leaves were clipped at the soil surface and put in paper bags along with dead leaves from earlier censuses. Roots were washed to remove the soil and then bagged separately from shoots. Biomass samples were dried at $55^{\circ} \mathrm{C}$ for a minimum of $96 \mathrm{~h}$, and then weighed. Three small sub-samples were cut fresh from each root system to assess AMF colonization. The root sub-samples were approximately $10 \times 25 \mathrm{~mm}$ each and cut from the top, middle, and bottom third of the root length. Root sub-samples were stored in a $48 \%$ ethanol solution until being processed for AMF evaluation.

\subsection{AMF Colonization Assessment}

Root samples were cleared and stained according to a modified Phillips and Hayman [42] procedure. During processing, root samples from each plant were contained in $28 \times 5$-mm tissue processing cassettes (Canemco Inc., Quebec, Canada). Roots were cleared in $10 \% \mathrm{KOH}$ solution and autoclaved at $130^{\circ} \mathrm{C}$ for $10 \mathrm{~min}$, and then acidified in a $1 \%$ HCL solution for $20 \mathrm{~min}$ at room temperature. Roots were stained in $0.05 \%$ Trypan blue staining solution containing 1:2:1 distilled water, lactic acid, and glycerin, and autoclaved for $7 \mathrm{~min}$ at $130^{\circ} \mathrm{C}$. Following staining, roots were rinsed in tap water and stored in pla- 
stic Petri dishes covered with a $1: 1$ solution of distilled water and glycerin and kept in a $4^{\circ} \mathrm{C}$ cooler. Colonization was assessed using a gridline intersect method $[43,44]$ in a plastic Petri dish with gridlines scored $13 \mathrm{~mm}$ apart on the bottom. For each sample, the first 50 roots bisecting gridlines were examined. Roots were designated colonized if the root segment contained hyphae, arbuscules, or vesicles; otherwise, they were designated non-colonized. Percent colonization was calculated by dividing the number of colonized roots by 50, then multiplying by 100 . The root sample was then dried at $55^{\circ} \mathrm{C}$ and weighed, and the dry weight was added back to the total root biomass.

\subsection{Statistical Analysis}

Data were analyzed using PROC GLM in SAS/STAT ${ }^{\circledR}$ software [45] and significance was accepted at $\alpha=0.05$. Main effects were SPP, AMF, and P. Post-hoc comparisons were made using protected Fisher's LSD test where differences were accepted only if the P-value calculated by PROC GLM was equal to or less than 0.05 [46]. Dependent variables were leaf number, shoot, root, and total biomass, root-to-shoot ratio (RSR), difference between $+\mathrm{AMF}$ and $-\mathrm{AMF}$ for shoot biomass difference (SDIFF), root biomass difference (RDIFF), total biomass difference (TDIFF), and AMF root colonization percent. Difference in biomass was calculated as a separate continuous random variable for each paired-pot comparison [47]. The null hypothesis for a paired-pot analysis is that the difference (D) between the two pairs is zero. Accepting the alternative hypothesis is based on the deviance from zero. Benefit from AMF inoculation was indicated by a positive outcome after subtracting the $-\mathrm{AMF}$ value from the $+\mathrm{AMF}$ value. Analysis of colonization percent only included the inoculated treatments in order to accurately reflect the level of infectivity of each inoculum.

\section{RESULTS}

\subsection{AMF Colonization as Affected by Soil $P$, Inoculum, and Grass Species}

The reclaimed mine soil used in this experiment initially averaged $12 \mathrm{mg} \cdot \mathrm{kg}^{-1} \mathrm{P}, 3768 \mathrm{mg} \cdot \mathrm{kg}^{-1}$ calcium $(\mathrm{Ca})$, and $\mathrm{pH}$ of 7.3 (Table 1). These values indicate a calcareous soil with limited available P. Mixing the soil with silica sand reduced the available $\mathrm{P}$ to $5 \mathrm{mg} \cdot \mathrm{kg}^{-1} \mathrm{cre}-$ ating critically low soil $\mathrm{P}$ for plant growth. Low $\mathrm{P}$ is conducive for testing and comparing the efficacy of the AMF strains. Furthermore, the addition of $\mathrm{P}$ acts as a control for the activity of AMF because it tests the efficacy of the AMF. Other nutrients were likely limiting, i.e. $\mathrm{N}$, but $\mathrm{P}$ is the primary nutrient associated with AMF
Table 1. Soil properties of reclaimed mine and AMF inoculum soil used to compare growth of prairie grasses with different concentrations of phosphorus (P) and different sources of arbuscular mycorrhizal fungi (AMF).

\begin{tabular}{ccccc}
\hline Soil Parameter $^{\mathrm{a}}$ & $\begin{array}{c}\text { Mine }^{\mathrm{b}} \\
\text { topsoil } \\
(0-20 \mathrm{~cm})\end{array}$ & $\begin{array}{c}\text { Sterile mine } \\
\text { soil/sand mix } \\
(1: 1)\end{array}$ & \multicolumn{2}{c}{ AMF source $^{\mathrm{c}}$} \\
\cline { 4 - 5 } $\mathrm{pH}$ & 7.3 & 7.3 & $\mathrm{CL}$ & $\mathrm{WL}$ \\
$\mathrm{P}\left(\mathrm{mg} \cdot \mathrm{kg}^{-1}\right)$ & 12 & 5 & $<1$ & 7.9 \\
$\mathrm{~K}\left(\mathrm{mg} \cdot \mathrm{kg}^{-1}\right)$ & 161 & 80 & 77 & 7 \\
$\mathrm{Ca}\left(\mathrm{mg} \cdot \mathrm{kg}^{-1}\right)$ & 3768 & 1722 & 1345 & 1262 \\
$\mathrm{Mg}\left(\mathrm{mg} \cdot \mathrm{kg}^{-1}\right)$ & 321 & 198 & 235 & 198 \\
\hline
\end{tabular}

${ }^{\mathrm{a} S}$ Soil analyzed by STAR lab, Wooster, OH. P analyzed with Bray P1 method; $\mathrm{K}, \mathrm{Ca}$, and $\mathrm{Mg}$ analyzed with ammonium acetate extract method. ${ }^{\mathrm{b}}$ Soil collected from the Wilds 30-yr reclaimed surface-mined land near Cumberland, $\mathrm{OH} .{ }^{\mathrm{c}} \mathrm{CL}$ collected from Claridon tallgrass prairie remnant near Marion, $\mathrm{OH}$; WL collected from the Wilds mine soil supporting non-native forage grasses. AMF inoculum soil prepared as pot-cultures containing a 1:1 mix of soil and silica sand.

function. Adding $\mathrm{N}$ to the pots would have increased growth, but then the activity of the AMF may have been confounded by amount of $\mathrm{N}$ taken up by each species, and in turn, how each species converted the added $\mathrm{N}$ into photosynthates to fuel the AMF. In our study, we found that neither AMF source nor $\mathrm{P}$ concentration had any effect on colonization percent when averaged over all other factors (Table 2). Grasses inoculated with either CL or WL averaged slightly greater than 50\% AMF colonization, indicating that both AMF cultures were equally accepted by the host grasses. The AMF colonization trended lower from $56 \%$ to $49 \%$ as $\mathrm{P}$ increased, but those differences were not significant (Table 2). Colonization differed among species, as tall dropseed and slender wheatgrass had the highest percentages with $70 \%$ and $55 \%$, respectively (Table 2). Big bluestem and Indiangrass had lowest colonization with $51 \%$ and $36 \%$, respectively.

\subsection{AMF and Soil P Effect on Plant Growth}

Response to soil $\mathrm{P}$ concentration was predictable, as an increase in $\mathrm{P}$ resulted in an increase in biomass production, and was most consistent for shoot biomass (Table 3). Total biomass also followed the same pattern, increasing with each increased level of P. However, root biomass did not increase from P2 to P3, thus P2 had the highest RSR, as the increased shoot growth at the higher $\mathrm{P}$ was not matched by a corresponding increase in root growth. This is likely a result of space limitation in the pots and not a lack of response to increased $\mathrm{P}$, as pots with the highest $\mathrm{P}$ level were densely packed with roots when harvested.

Slender wheatgrass produced the greatest total biomass, which was similarly split between root and shoot 
Table 2. Percent colonization by arbuscular mycorrhizal fungi (AMF) as affected by AMF sources, soil phosphorus level (P), and grass species (SPP) in a 16-week glasshouse experiment.

\begin{tabular}{cc}
\hline Parameter & Colonization $^{\mathrm{a}}$ \\
\hline AMF & $(\%)$ \\
CL & $52.3 \mathrm{a}$ \\
WL & $53.1 \mathrm{a}$ \\
& $(\mathrm{P}=0.7917)$ \\
$\mathrm{P}^{\mathrm{b}}$ & $55.6 \mathrm{a}$ \\
P1 & $53.7 \mathrm{a}$ \\
P2 & $48.9 \mathrm{a}$ \\
P3 & $(\mathrm{P}=0.2271)$ \\
& \\
SPP & $51.0 \mathrm{bc}$ \\
Big bluestem & $35.5 \mathrm{c}$ \\
Indiangrass & $69.9 \mathrm{a}$ \\
Tall dropseed & $54.7 \mathrm{ab}$ \\
Slender wheatgrass & $(\mathrm{P}=0.0226)$ \\
\hline
\end{tabular}

${ }^{a}$ Colonization percents reflect only plants inoculated with AMF. Non-inoculated plants had $0 \%$ AMF colonization. Differences within each variable are determined using protected Fisher's $\operatorname{LSD}(\alpha=0.05)$. Means followed by the same lower-case letter $(\mathrm{a}, \mathrm{b}, \mathrm{c})$ are not different. ${ }^{\mathrm{b}} \mathrm{P}$ target levels were $\mathrm{P} 1=$ $5 \mathrm{mg} \cdot \mathrm{kg}^{-1} \mathrm{P} ; \mathrm{P} 2=13 \mathrm{mg} \cdot \mathrm{kg}^{-1} \mathrm{P} ; \mathrm{P} 3=27 \mathrm{mg} \cdot \mathrm{kg}^{-1} \mathrm{P}$.

Table 3. Biomass production as affected by grass species (SPP) and three levels of soil phosphorus (P) in a 16-week glasshouse experiment.

\begin{tabular}{ccccc}
\hline & \multicolumn{4}{c}{ Dependent variables $^{\mathrm{a}}$} \\
\cline { 2 - 5 } Main effects & Shoot & Root & Total & $\mathrm{RSR}^{\mathrm{b}}$ \\
\hline SPP & & $(\mathrm{g}$ dry weight $)$ & $(\mathrm{g} / \mathrm{g})$ \\
Big bluestem & $0.7 \mathrm{c}$ & $1.5 \mathrm{a}$ & $2.2 \mathrm{~b}$ & $2.4 \mathrm{a}$ \\
Indiangrass & $0.7 \mathrm{c}$ & $1.1 \mathrm{~b}$ & $1.8 \mathrm{c}$ & $1.8 \mathrm{~b}$ \\
Tall dropseed & $1.1 \mathrm{~b}$ & $0.7 \mathrm{c}$ & $1.8 \mathrm{c}$ & $0.7 \mathrm{c}$ \\
Slender & $1.5 \mathrm{a}$ & $1.3 \mathrm{ab}$ & $2.8 \mathrm{a}$ & $0.9 \mathrm{c}$ \\
wheatgrass & & & & \\
& $(\mathrm{P}<0.0001)$ & $(\mathrm{P}<0.0001)$ & $(\mathrm{P}<0.0001)$ & $(\mathrm{P}<0.0001)$ \\
$\mathrm{P}^{\mathrm{c}}$ & & & & \\
P1 & $0.6 \mathrm{c}$ & $0.7 \mathrm{~b}$ & $1.4 \mathrm{c}$ & $1.5 \mathrm{ab}$ \\
$\mathrm{P} 2$ & $1.0 \mathrm{~b}$ & $1.4 \mathrm{a}$ & $2.4 \mathrm{~b}$ & $1.6 \mathrm{a}$ \\
$\mathrm{P} 3$ & $1.3 \mathrm{a}$ & $1.4 \mathrm{a}$ & $2.7 \mathrm{a}$ & $1.3 \mathrm{~b}$ \\
& $(\mathrm{P}<0.0001)$ & $(\mathrm{P}<0.0001)$ & $(\mathrm{P}<0.0001)$ & $(\mathrm{P}=0.0231)$ \\
\hline
\end{tabular}

${ }^{\mathrm{a}} \mathrm{P}$-values represent the probability of differences within each dependent variable for each main-effect. Differences within each variable are determined using protected Fisher's LSD $(\alpha=0.05)$. Means followed by the same lower-case letter $(\mathrm{a}, \mathrm{b}, \mathrm{c})$ are not different. ${ }^{\mathrm{b}}$ Root to shoot ratio (RSR) calculated by dividing root weight by shoot weight. ${ }^{\mathrm{C}}$ See Table 2 for target $\mathrm{P}$ levels.

biomass (Table 3). Big bluestem had similar root biomass compared with slender wheatgrass, but only produced half the shoot biomass. The difference in allocation of resources between these species was reflected in the RSR, as slender wheatgrass averaged 0.9 while big bluestem averaged 2.4 (Table 3 ). Indiangrass and tall dropseed produced the least total biomass; however, Indiangrass allocated more resources to root biomass, while tall dropseed allocated more resources to shoot production. This indicates that big bluestem and Indiangrass appear to direct more resources, proportionately, to root growth during seedling establishment, compared with slender wheatgrass and tall dropseed.

\subsection{AMF Effectivity in Paired-Pot Comparison}

To compare the effectiveness of the AMF cultures, a paired-pot arrangement was used to examine the difference in biomass accumulation between colonized and non-colonized plants. By subtracting the biomass of a -AMF plant from an adjacent +AMF plant for each component (shoot/root/total), new variables were created that, if positive, indicated AMF benefit, and if negative, indicated AMF detriment. The GLM analysis indicated that SPP and P had the greatest influence on shoot difference (SDIFF), root difference (RDIFF), and total difference (TDIFF), with P-values $<0.0001$ (Table 4). In contrast, AMF had a significant impact only on SDIFF (Table 4).

There was a significant interaction between AMF and $P$ for RDIFF and TDIFF, influenced mainly by RDIFF (Table 4). For SDIFF, AMF benefit was positive for both CL and WL at P1, but decreased for CL with each increase in $\mathrm{P}$, whereas there was no decreased benefit for WL at P3 (Figure 1(a)). There was no difference in AMF benefit for RDIFF between P1 and P2 for CL AMF, which was negative at all three $\mathrm{P}$ levels (Figure 1(b)); however, WL AMF was positive at P1 but negative at both $\mathrm{P} 2$ and P3, with the least benefit occurring at P2 (Figure 1(b)). For TDIFF, the benefit of both AMF sources was positive at P1, but negative at P2 and P3 (Figure 1(c)). The interactions between AMF and $\mathrm{P}$, for all three difference variables, occurred as the response to increasing $\mathrm{P}$ differed between AMF sources.

Significant interactions were also found between SPP and $\mathrm{P}$ for all three difference variables. Overall, the only AMF benefit occurred with big bluestem, Indiangrass only at the lowest P level (Figure 2). For SDIFF, benefit decreased as P increased for big bluestem, Indiangrass, and slender wheatgrass, but tall dropseed was not affected (Figure 2(a)). In addition, slender wheatgrass experienced negative benefit at all three P levels. For RDIFF, both tall dropseed and slender wheatgrass had negative benefit at all three $\mathrm{P}$ levels and was not affected by an increase in P (Figure 2(b)). Big bluestem RDIFF declined with each increase in $\mathrm{P}$ while Indiangrass declined only from P1 to P2. The interactions with TDIFF were very similar to RDIFF (Figure 2(c)).

The interaction between SPP and P was also evident in the number of leaves produced during the 16-week expe- 
Table 4. Analysis of variance table (PROC GLM) for the full model with a factorial arrangement testing the difference in biomass production for grass species (SPP) colonized with arbuscular mycorrhizal fungi (+AMF) and non-AMF (-AMF) plants. Dependent variables shoot difference (SDIFF), root difference (RDIFF), and total difference (TDIFF) were produced by subtracting biomass of - AMF plants from + AMF plants in a paired-pot glasshouse experiment examining the effects of AMF source and $P$ on growth of prairie SPP grown in sterilized mine soil.

\begin{tabular}{cccccccc}
\hline & \multicolumn{2}{c}{ SDIFF } & \multicolumn{2}{c}{ RDIFF } & \multicolumn{2}{c}{ TDIFF } \\
\hline Model & DF & F value & P $>$ F & F value & P $>$ F & F value & P $>$ F \\
\hline BLOCK & 5 & 0.4 & 0.8753 & 2.2 & 0.0601 & 1.2 & 0.3225 \\
SPP & 3 & 15.5 & $<0.0001$ & 19.2 & $<0.0001$ & 25.5 & $<0.0001$ \\
AMF & 1 & 6.0 & 0.0162 & 0.6 & 0.4294 & 0.2 & 0.6244 \\
P & 2 & 38.9 & $<0.0001$ & 29.4 & $<0.0001$ & 51.2 & $<0.0001$ \\
SPPXMF & 3 & 0.7 & 0.5354 & 2.8 & 0.0461 & 2.8 & 0.0428 \\
SPPxP & 6 & 3.9 & 0.0013 & 3.3 & 0.0053 & 5.2 & $<0.0001$ \\
AMFxP & 2 & 2.8 & 0.0629 & 15.6 & $<0.0001$ & 13.1 & $<0.0001$ \\
SPPxAMFxP & 6 & 0.5 & 0.8391 & 0.7 & 0.6449 & 0.9 & 0.5276 \\
TOTAL & 141 & & & & & & \\
\hline
\end{tabular}

riment (Figure 3). At P1, leaf production at each census was greater for mycorrhizal big bluestem, Indiangrass, and tall dropseed compared with non-mycorrhizal plants. Indiangrass appeared to have the greatest AMF benefit, whereas +AMF slender wheatgrass produced slightly more leaves only at 4 weeks (Figure 3).

At P2 and P3, AMF effect was less evident for all grass species except slender wheatgrass where -AMF plants produced the greatest number of leaves (Figure 3). The interaction between SPP and P at these levels of P would indicate that the cool-season slender wheatgrass is negatively affected by AMF when $\mathrm{P}$ is abundantly available, whereas the warm-season grasses (big bluestem, Indiangrass, and tall dropseed) are less affected (Figure 3). Slender wheatgrass appears to gain little, if any, benefit from AMF, which would suggest this species would be useful in restoration plantings where AMF is not initially present.

\section{DISCUSSION}

A number of studies have shown that AMF colonization is reduced by higher soil P [48-51], but that was not evident in this study. If plants can obtain $\mathrm{P}$ on their own then symbiosis would be less beneficial. However, there is often no clear relationship between colonization percent and $\mathrm{P}$ uptake or plant growth response [52-54], meaning that efficacy is not necessarily related to the magnitude of colonization. It is known that warm-season grasses tend to be more dependent on AMF than coolseason grasses, especially when $\mathrm{P}$ is limited [35]. Coolseason grasses tend to have finer root systems that are better suited for $\mathrm{P}$ uptake, while warm-season grasses tend to have more coarse root systems. The high abundance of AMF in slender wheatgrass roots was unexpected. Big bluestem is known to be very dependent on AMF [55] and is a dominant species in tallgrass prairies across North America. The mycorrhizal status of tall dropseed has not been reported, but a related species, Sporobolus heterolepis, is mycorrhizal [56].

Big bluestem and Indiangrass responded to AMF and $\mathrm{P}$ as expected according to previous research [55]. Both species benefited from AMF when soil $\mathrm{P}$ was low, and showed less benefit as $\mathrm{P}$ increased. Both of these grasses allocated more resources to roots than aboveground tissue, which is important for access to nutrients and water during periods of stress. Harris [57] determined that competitive success of non-native downy brome (Bromus tectorum L.) was due to its ability to establish a deep root system during autumn and winter when native bluebunch wheatgrass (Pseudoroegneria spicata (Pursh) A. Löve) was dormant. During spring, a downy brome infestation depleted soil moisture before bluebunch wheatgrass was able to complete its reproductive cycle. The dominance of big bluestem and Indiangrass in tallgrass prairies is likely due to their ability to establish deep root systems over time, as well as their association with AMF when soil P is limited.

Tall dropseed and slender wheatgrass both appear facultative in their response to AMF. Tall dropseed is a warmseason prairie grass, but seems to respond to AMF and P similarly to facultative cool-season grasses. Greater production of aboveground biomass compared with root biomass and low dependence on AMF would suggest that tall dropseed can quickly establish following disturbance in habitats where P and AMF may be limiting. Slender wheatgrass forms association with AMF, but is clearly not dependent on AMF. It is able to access $\mathrm{P}$ when soil levels are low, and can be very productive when soil $\mathrm{P}$ is higher.

\section{CONCLUSIONS}

Results of this research indicate that AMF associated with reclaimed mine soil are not likely a barrier for es- 

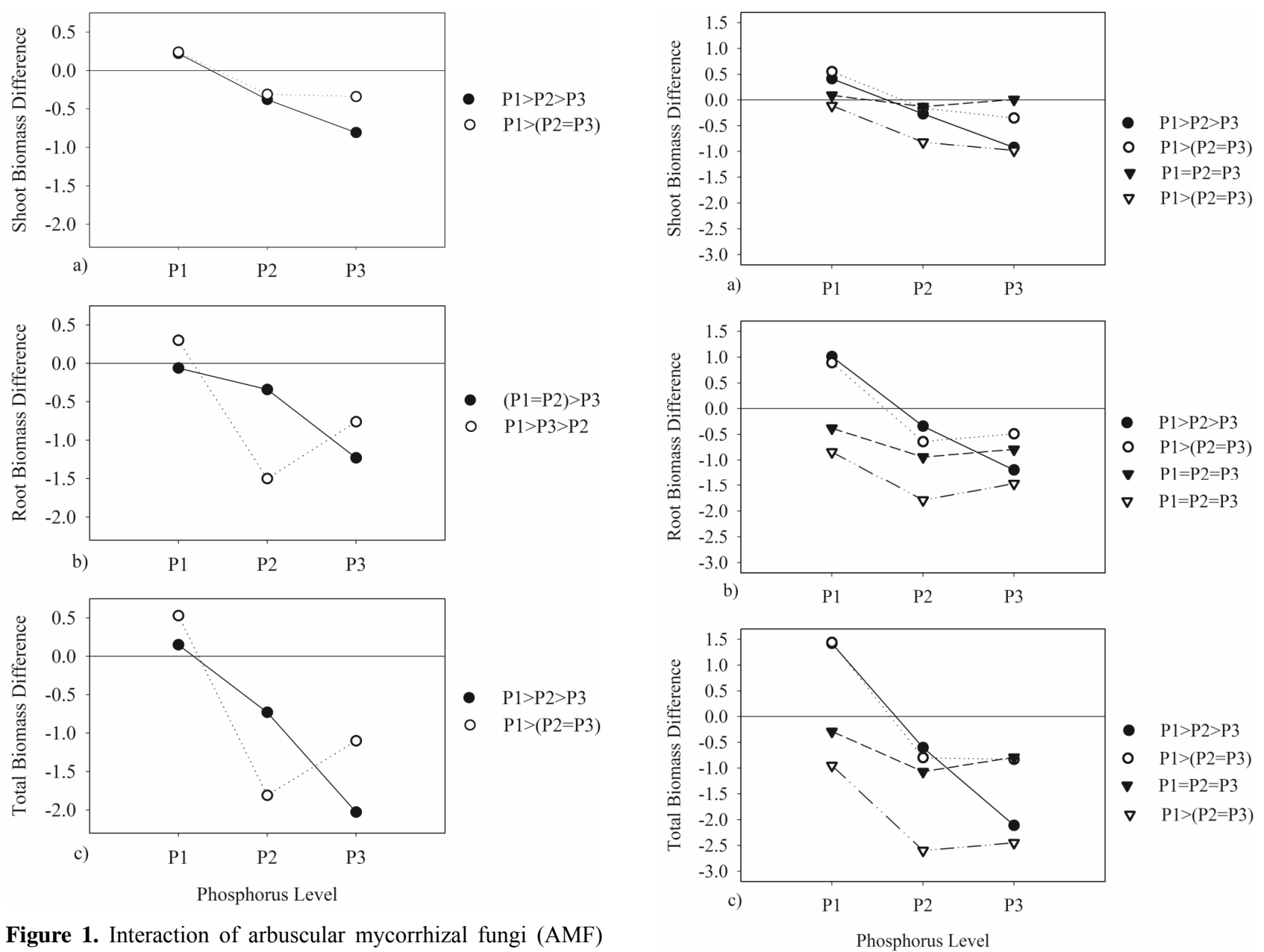

Figure 1. Interaction of arbuscular mycorrhizal fungi (AMF) from the Claridon tallgrass prairie remnant $(\mathrm{CL})$ and the Wilds reclaimed mine soil (WL) in Ohio and soil phosphorus level (P1, P2, P3). Values represent the difference in biomass between AMF-colonized and non-colonized grasses a in a 16-week glasshouse experiment measuring shoot biomass difference (SDIFF), root biomass difference (RDIFF), and total biomass difference (TDIFF). Solid lines (-) represent CL-AMF comparisons; dotted lines (…) represent WL-AMF comparisons. Differences at each phosphorus level within each graph $(\alpha=$ $0.05)$ are shown to the right.

tablishing tallgrass prairie species. Colonization levels were similar between the two AMF inoculums. This would also suggest that host specificity is not a deterrent for native grass establishment even though the mine soil AMF have been associated with non-native cool-season forage species for 30 years. It appears that poor soil conditions of the mine soil, i.e. compacted calcareous soil with low available phosphorus, may have selected an effective AMF community, which could benefit native tallgrass prairie grasses.

Tall dropseed and slender wheatgrass both appear to establish well when P is low, with or without AMF, and would be useful in early establishment of a prairie community on reclaimed mine soil. Big bluestem and Indiangrass are more dependent on AMF, but did benefit from

Figure 2. Interaction of grass species (SPP) and soil phosphorous concentration $(\mathrm{P})$ on the difference in biomass between grasses colonized with arbuscular mycorrhizal fungi (AMF) and non-colonized grasses in a 16-week glasshouse experiment measuring shoot (SDIFF), root (RDIFF), and total biomass measurements (TDIFF). Solid lines (--) represent big bluestem; dotted lines $(\cdots)$ represent Indiangrass; dashed lines $(--)$ represent tall dropseed; dashed and dotted lines $(-\cdot--)$ represent slender wheatgrass. Differences at each phosphorus level within each graph are shown to the right and determined using a protected Fisher's LSD $(\alpha=0.05)$.

the mine soil AMF in this study. This study suggests that years of growth by non-native cool-season forage species on reclaimed compacted mine soil in southeast Ohio have propagated AMF that would aid in the establishment of native AMF-dependent warm season prairie grasses. The ecological significance of these findings is that in highly disturbed landscapes there are many potential ways for ecosystems to self organize. The non-native species planted during reclamation were a valuable nurse crop for the indigenous AMF, but did not yield a diverse landscape. By adding more species that can utilize the AMF, the low diversity issue may be addressed and a new era of self organization could lead to more function, structure, and 


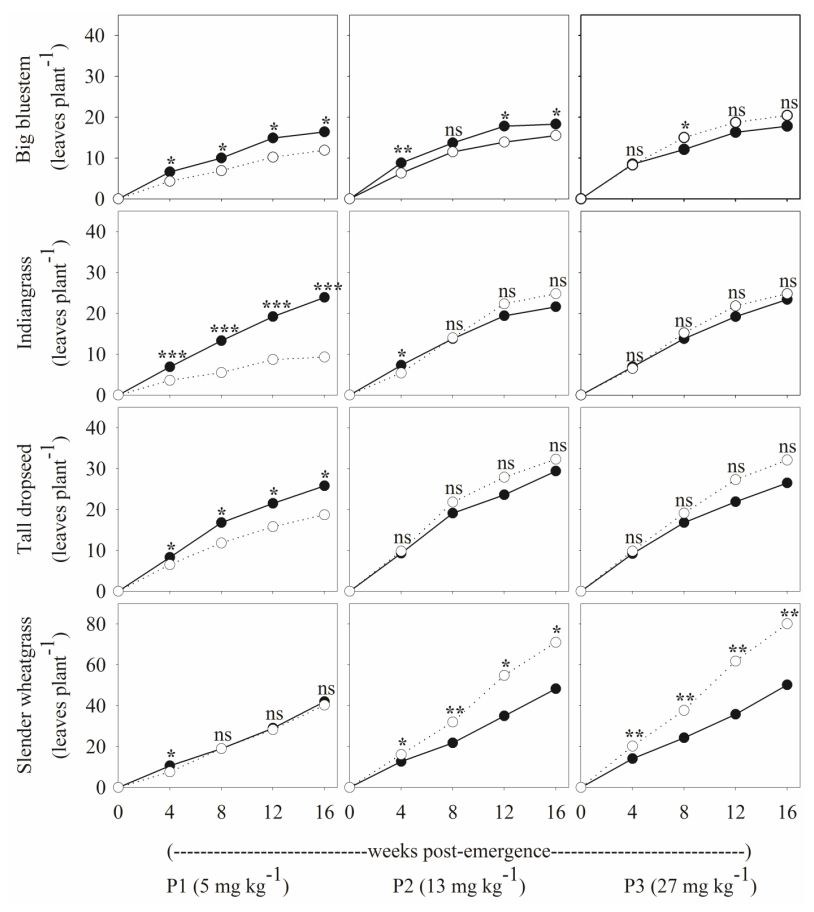

Figure 3. Arbuscular mycorrhizal fungi (AMF) effect on number of leaves produced by prairie grasses at three concentrations of soil phosphorus $(\mathrm{P})$ level during a 16-week glasshouse experiment. Solid lines $(-)$ represent AMF colonized; dotted lines (‥) represent non-AMF colonized plants. P-values are signified as follows: $*=0.05<\mathrm{P}<0.001, * *=0.001<\mathrm{P}<$ $0.0001, * * *=\mathrm{P}<0.0001$, and $\mathrm{ns}=\mathrm{P}>0.05$ between AMF and non-AMF plants at each sampling.

productivity from the landscape.

\section{ACKNOWLEDGEMENTS}

We thank Dr. Nicole Cavender for access to soil at the Wilds; Dr. Robert Klips for access to soil at the Claridon Prairie; Dr. Marc Evans for statistical consultation; and Drs. Craig Davis and James Metzger for comments on the manuscript. We also thank David Snodgrass and Jim Vent of the Howlett Greenhouse facility at The Ohio State University for assistance with this project. Salaries and research support were provided by state and federal funds appropriated to the Ohio Agriculture Research and Development Center, The Ohio State University. Manuscript No. HCS13-04.

\section{REFERENCES}

[1] Gould, A.B. and Liberta, A.E. (1981) Effects of topsoil storage during surface mining on the viability of vesicular-arbuscular mycorrhiza. Mycologia, 73, 914-921. doi: $10.2307 / 3759802$

[2] Waaland, M.E. and Allen, E.B. (1987) Relationship between VA mycorrhizal fungi and plant cover following surface mining in Wyoming. Journal of Range Management, 40, 271-276. doi:10.2307/3899096

[3] Lambert, D.H. and Cole Jr., H. (1980) Effects of my- corrhizae on establishment and performance of forage species in mine spoil. Agronomy Journal, 72, 257-260. doi:10.2134/agronj1980.00021962007200020003x

[4] Allen, E.B. (1989) The restoration of disturbed arid landscapes with special reference to mycorrhizal fungi. Journal of Arid Environments, 17, 279-286.

[5] Hetrick, B.A.D., Wilson, G.W.T. and Figge, D.A.H. (1994) The influence of mycorrhizal symbiosis and fertilizer amendments on establishment of vegetation in heavy metal mine spoil. Environmental Pollution, 86, 171-179. doi:10.1016/0269-7491(94)90188-0

[6] Gerdemann, J.W. (1968) Vesicular-arbuscular mycorrhiza and plant growth. Annual Review of Phytopathology, 6, 397-418. doi:10.1146/annurev.py.06.090168.002145

[7] Rhodes, L.H. and Gerdemann, J.W. (1975) Phosphate uptake zones of mycorrhizal and non-mycorrhizal onions. New Phytologist, 75, 555-561. doi:10.1111/j.1469-8137.1975.tb01419.x

[8] Barrow, N.J., Malajczuk, N. and Shaw, T.C. (1977) A direct test of the ability of vesicular-arbuscular mycorrhizae to help plants take up fixed soil phosphate. New Phytologist, 78, 269-276. doi:10.1111/j.1469-8137.1977.tb04830.x

[9] Smith, F.A. and Smith, S.E. (1997) Structural diversity in (vesicular)-arbuscular mycorrhizal symbiosis. New Phytologist, 137, 373-388. doi:10.1046/j.1469-8137.1997.00848.x

[10] Cavagnaro, T.R., Smith, F.A., Smith, S.E. and Jakobsen, I. (2005) Functional diversity in arbuscular mycorrhizas: exploitation of soil patches with different phosphate enrichment differs among fungal species. Plant Cell and Environment, 28, 642-650. doi:10.1111/j.1365-3040.2005.01310.x

[11] Brejda, J.J., Yocom, D.H., Moser, L.E. and Waller, S.S. (1993) Dependence of 3 Nebraska Sandhills warm-season grasses on vesicular-arbuscular mycorrhizae. Journal of Range Management, 46, 14-20. doi:10.2307/4002441

[12] Janos, D.P. (1980) Mycorrhizae influence tropical succession. Biotropica, 12, 56-64. doi:10.2307/2388157

[13] Allen, E.B. and Allen, M.F. (1984) Competition between plants of different successional stages: Mycorrhizae as regulators. Canadian Journal of Botany, 62, 2625-2629. doi:10.1139/b84-356

[14] Crowell, H.F. and Boerner, R.E.J. (1988) Influences of mycorrhizae and phosphorus on belowground competetion between two old-field annuals. Environmental and Experimental Botany, 28, 381-392. doi:10.1016/0098-8472(88)90063-9

[15] Gange, A.C., Brown, V.K. and Farmer, L.M. (1990) A test of mycorrhizal benefit in an early successional plant community. New Phytologist, 115, 85-91. doi:10.1111/j.1469-8137.1990.tb00925.x

[16] Allen, M.F. and Allen, E.B. (1992) Mycorrhizae and plant community development: Mechanisms and patterns. In: Carrol, G.C. and Wicklow, D.T., Eds., The Fungal Community: Its Organization and Role in the Ecosystem. Mycology Series 9, Marcel Dekker, Inc., New York.

[17] Gange, A.C., Brown, V.K. and Sinclair, G.S. (1993) Vesi- 
cular-arbuscular mycorrhizal fungi: A determinant of plant community structure in early succession. Functional Eco$\log y$, 7, 616-622. doi:10.2307/2390139

[18] Hartnett, D.C., Samenus, R.J., Fischer, L.E. Hetrick, B.A.D. (1994) Plant demographic response to mycorrhizal symbiosis in tallgrass prairie. Oecologia, 99, 21-26. doi:10.1007/BF00317079

[19] Koske, R.E. and Gemma, J.N. (1997) Mycorrhizae and succession in planting of beachgrass in sand dunes. American Journal of Botany, 84, 118-130. doi:10.2307/2445889

[20] Gillespie, I.G. and Allen, E.B. (2006) Effects of soil and mycorrhizae from native and invaded vegetation on a rare California forb. Applied Soil Ecology, 32, 6-12. doi:10.1016/j.apsoil.2005.03.008

[21] Scullion, J., Eason, W.R. and Scott, E.P. (1998) The effectivity of arbuscular mycorrhizal fungi from high input conventional and organic grassland and grass-arable rotations. Plant and Soil, 204, 243-254. doi:10.1023/A:1004319325290

[22] Henkel, T.W., Smith, W.K. and Christensen, M. (1989) Infectivity and effectivity of indigenous vesicular-arbuscular mycorrhizal fungi from contiguous soils in southwestern Wyoming, USA. New Phytologist, 112, 205214. doi:10.1111/j.1469-8137.1989.tb02375.x

[23] Shetty, K.G., Hetrick, B.A.D. and Schwab, A.P. (1995) Effects of mycorrhizae and fertilizer amendments on zinc tolerance of plants. Environmental Pollution, 88, 307-314. doi:10.1016/0269-7491(95)93444-5

[24] Thorne, M.E., Zamora, B.A. and Kennedy, A.C. (1998) Sewage sludge and mycorrhizal effects on Secar bluebunch wheatgrass in mine spoil. Journal of Environmental Quality, 27, 1228-1233. doi:10.2134/jeq1998.00472425002700050030x

[25] Zhu, Y.G., Laidlaw, A.S., Christie, P. and Hammond, M.E.R. (2000) The specificity of arbuscular mycorrhizal fungi in perennial ryegrass-white clover pasture. Agriculture Ecosystems and Environment, 77, 211-218. doi:10.1016/S0167-8809(99)00087-0

[26] Ronsheim, M.L. and Anderson, S.E. (2001) Populationlevel specificity in the plant-mycorrhizae associations alters intraspecific interactions among neighboring plants. Oecologia, 128, 77-84. doi:10.1007/s004420000625

[27] Bevor, J.D. (2002) Host-specificity of AM fungal population growth rates can generate feedback on plant growth. Plant and Soil, 244, 281-290. doi:10.1023/A:1020221609080

[28] Sanders, I.R. (2003) Preference, specificity and cheating in the arbuscular mycorrhizae symbiosis. Trends in Plant Science, 8, 143-145. doi:10.1016/S1360-1385(03)00012-8

[29] Kaster, G. and Vimmerstedt, J.P. (1996) Tree planting on strip-mined land. In: Norland, E.R. and Ervin, M.S., Eds., Forest Resource Issues in Ohio 1996, Legislator's Handbook, 2nd Edition. Ohio Society of American Foresters, Columbus.

[30] SMCRA (1977) (Surface Mining Control and Reclamation Act) Office of Surface Mining Reclamation and En- forcement, US Department of Interior, Washington DC.

[31] Transeau, E.N. (1935) The prairie peninsula. Ecology, 3, 423-437. doi: $10.2307 / 1930078$

[32] Sala, O.E., Patron, W.J., Joyce, L.A. and Lauenroth, W.K. (1988) Primary production of the central grassland region of the United States. Ecology, 69, 40-45. doi: $10.2307 / 1943158$

[33] Klips, R.A. (2003) Vegetation of Claridon railroad prairie, a remnant of the Sandusky Plains of central Ohio. Castanea, 68, 135-142.

[34] Loree, M.A.J. and Williams, S.E. (1987) Colonization of western wheatgrass (Agropyron smithii Rydb.) by vesicular-arbuscular mycorrhizal fungi during the revegetation of a surface mine. New Phytologist, 106, 735-744. doi:10.1111/j.1469-8137.1987.tb00174.x

[35] Hetrick, B.A.D., Wilson, G.W.T. and Leslie, J.F. (1991) Root architecture of warm- and cool-season grasses: relationship to mycorrhizal dependence. Canadian Journal of Botany, 69, 112-118. doi:10.1139/b91-016

[36] Noyd, R.K., Pfleger, F.L. and Russelle, M.P. (1995) Interactions between native prairie grasses and indigenous arbuscular mycorrhizal fungi: Implications for reclamation of taconite iron ore tailing. New Phytologist, 129, 651-660. doi:10.1111/j.1469-8137.1995.tb03034.x

[37] Cavender, N. and Knee, M. (2006) Relationship of seed source and arbuscular mycorrhizal fungi inoculum type to growth and colonization of big bluestem (Andropogon gerardii). Plant and Soil, 285, 57-65. doi:10.1007/s11104-005-5228-2

[38] Hitchcock, A.S. (1971) Manual of the grasses of the United States. Dover Public, New York.

[39] Taheri, W.I. and Bevor, J.D. (2010) Adaptation of plants and arbuscular mycorrhizal fungi to coal tailings in Indiana. Applied Soil Ecology, 45, 138-143.

[40] Simmons, J.A., Currie, W.S., Eshleman, K.N., Kuers, K., Monteleone, S., Negley, T.L., Pohlad, B.R. and Thomas, C.L. (2008) Forest to reclaimed mine land use change leads to altered ecosystem structure and function. Ecological Applications, 18, 104-118.

[41] Liu, R. and Wang, F. (2003) Selection of appropriate host plants used in trap culture of arbuscular mycorrhizal fungi. Mycorrhiza, 13, 123-127. doi:10.1007/s00572-002-0207-4

[42] Phillips, J.M. and Hayman, D.S. (1970) Improved procedures for clearing roots and staining parasitic and vesicular-arbuscular mycorrhizal fungi for rapid assessment of infection. Transactions of the British Mycological Society, 5, 158-161. doi:10.1016/S0007-1536(70)80110-3

[43] Newman, E.I. (1966) A method of estimating the total length of root in a sample. Journal of Applied Ecology, 3, 139-145. doi: $10.2307 / 2401670$

[44] Giovannetti, M. and Mosse, B. (1980) An evaluation of techniques for measuring vesicular arbuscular mycorrhizal infection in roots. New Phytologist, 84, 489-500. doi:10.1111/j.1469-8137.1980.tb04556.x

[45] SAS Institute Inc. (2002) SAS OnlineDoc, Version 9.1.3. http://support.sas.com/onlinedoc/913/docMainpage.jsp. 
[46] Milliken, G.A. and Johnson, D.E. (1984) Analysis of messy data, Volume I: Designed experiments. Wadsworth, Inc., Belmont.

[47] Zar, J.H. (1999) Biostatistical analysis. 4th Edition, Prentice-Hall, Inc., Upper Saddle River.

[48] Mosse, B. (1973) Plant growth responses to vesicular-arbuscular mycorrhiza IV. In soil given additional phosphate. New Phytologist, 72, 127-136. doi:10.1111/j.1469-8137.1973.tb02017.x

[49] Schubert, A. and Hayman, D.S. (1986) Plant growth responses to vesicular-arbuscular mycorrhiza. XVI. Effectiveness of different endophytes at different levels of soil phosphate. New Phytologist, 103, 79-90. doi:10.1111/j.1469-8137.1986.tb00598.x

[50] Sainz, M.J. and Arines, J. (1988) Effects of native vesicular-arbuscular mycorrhizal fungi and phosphate fertilizer on red clover growth in acid soils. Journal of Agricultural Science Cambridge, 111, 67-73. doi: $10.1017 / \mathrm{S} 0021859600082824$

[51] Al-Karaki, G.N. and Al-Omoush, M. (2002) Wheat response to phosphogypsum and mycorrhizal fungi in alkaline soil. Journal of Plant Nutrition, 25, 873-883. doi:10.1081/PLN-120002966

[52] Lioi, L. and Giovannetti, M. (1987) Variable effectivity of three vesicular-arbuscular mycorrhizal endophytes in $\mathrm{He}$ dysarum coronarium and Medicago sativa. Biology and Fertility of Soils, 4, 193-197. doi:10.1007/BF00270940

[53] Sanders, I.R. and Fitter, A.H. (1992) The ecology and functioning of vesicular-arbuscular mycorrhizas in coexisting grassland species. New Phytologist, 120, 525-533. doi:10.1111/j.1469-8137.1992.tb01802.x

[54] Mohammad, M.J., Pan, W.L. and Kennedy, A.C. (1995) Wheat response to vesicular-arbuscular mycorrhizal fungal inoculation of soils from eroded toposequence. Soil Science Society of America Journal, 59, 1086-1090. doi:10.2136/sssaj1995.03615995005900040020x

[55] Hetrick, B.A.D., Kitt, D.G. and Wilson, G.T. (1986) The influence of phosphorus fertilization, drought, fungal species, and nonsterile soil on mycorrhizal growth response in tall grass prairie plants. Canadian Journal of Botany, 64, 1199-1203. doi:10.1139/b86-162

[56] Dhillion, S.S. (1992) Evidence for host-mycorrhizal preference in native grassland species. Mycological Research, 96, 359-362. doi:10.1016/S0953-7562(09)80951-9

[57] Harris, G.A. (1967) Some competitive relationships between Agropyron spicatum and Bromus tectorum. Ecological Monographs, 37, 89-111. doi:10.2307/2937337 